\title{
FORMALISASI HUKUM ISLAM KEDALAM TATA HUKUM INDONESIA
}

\author{
Tomi Agustian
}

Dosen Institut Agama Islam Negeri Curup

tomiagustian48@gmail.com

\begin{tabular}{|c|c|}
\hline & Abstrak \\
\hline $\begin{array}{l}\text { Article History } \\
\text { Received : 31-01-2019 } \\
\text { Revised : 01-02-2019 } \\
\text { Accepted : 06-02-2019 } \\
\text { Keywords : } \\
\text { Transformatio } \\
\text { n, Islamic Law, } \\
\text { The Law Of } \\
\text { Indonesia }\end{array}$ & $\begin{array}{l}\text { Islamic law is one of the raw materials } \\
\text { for the national legal systems in addition } \\
\text { to the customary law and the law of the } \\
\text { West.Therefore Islamic law can be used } \\
\text { as raw material for the construction of } \\
\text { the device, order and culture of origin of } \\
\text { national law does not conflict with the } \\
\text { values of Pancasila and the } 1945 \\
\text { CONSTITUTION and in accordance with } \\
\text { the needs of the people of Indonesia } \\
\text { law.Can not be contradicted by evidence } \\
\text { of any kind that Islamic law has an } \\
\text { important and strategic position in } \\
\text { national law drafting and pmbentukan } \\
\text { Indonesia One of the efforts to } \\
\text { incorporate Islamic law into the national } \\
\text { laws of grammar through } \\
\text { transformation.This paper discusses } \\
\text { about the effort will be the } \\
\text { transformation of Islamic law into the } \\
\text { law of Indonesia governance. the } \\
\text { formalization of Islamic law if done } \\
\text { substantively, cannot be released and } \\
\text { must be preceded by a reference to the } \\
\text { judiciary with constitutional } \\
\text { considerations and the history of the } \\
\text { nation. The process is inseparable from } \\
\text { the history of Islamic law in Indonesia, } \\
\text { and the policy of Indonesian legal } \\
\text { politics in placing the position of Islamic } \\
\text { law in the national legal system. }\end{array}$ \\
\hline
\end{tabular}




\section{Pendahuluan}

Berbagai pengkajian tentang hukum Islam dalam konteks apapun dan dalam bentuk apapun, pada dasarnya merupakan suatu upaya untuk memahami kemudian mendeskripsikan serta menjelaskan berbagai dimensi dan substansi hukum Islam sebagai bagian dari kehidupan manusia yang dapat digali dari berbagai sumber yang mudah ditemukan. Salah satu pendapat yang didapat melalui pengkajian itu adalah bahwa hukum Islam adalah hukum seperti yang dipahami oleh para fuqaha (fiqh) sepanjang masa. (Rifyal Ka'bah. 2007: 1) Oleh karena itu hukum Islam sebenarnya dapat dikemas sebagai sesuatu yang dapat dikembangkan melalui interpretasi, yang sangat bermanfaat bagi pengembangan pengkajian serta pengetahuan yang bersifat ilmiah, maupun bagi pemahaman masalah hukum untuk dipedomani dalam hidup berbangsa dan bernegara.

Dalam konteks Indonesia, kehadiran Islam dan hukum Islam merupakan mata rantai yang tidak mungkin dipisahkan dari fakta historis lahirnya republik ini. Sejak diproklamirkannya kemerdekaan Indonesia pada tanggal 17 Agustus 1945 dimulailah era baru dalam tata hukum di bumi Nusantara ini yang memisahkan antara hukum kolonial dengan tata hukum nasional. Menurut Ismail Saleh hingga saat ini Indonesia belum memiliki suatu sistem hukum yang bersifat nasional, dalam arti suatu sistem yang bulat, terpadu dan berakar kuat serta tumbuh dan berkembang dari sistem nilai dan norma dasar serta filsafat bangsa yang mengabdi kepada suatu kepentingan nasional.( Ismail Saleh, 1990:123)

Namun timbul pertanyaan yang lebih pelik lagi untuk dijawab setelah didalami dan dikupas lebih dalam, apa hukum nasional itu? Jawabannya tidak mudah untuk menunjukkan bentuk yang matang. Sosok hukum nasional tidak mudah ditunjuk. Mungkin salah satu sebabnya adalah bahwa hukum nasional itu sendiri belum mengkristal menunjukkan sosok gerangan nyata yang dapat langsung dipakai Itulah sebabnya, maka terjadi perdebatan yang panjang dan melelahkan. Namun paling tidak ada "kesepakatan" bahwa hukum nasional itu hukum yang bersumber dari tiga sumber: hukum modern atau internasional (yang asalnya Belanda), hukum adat atau kebiasaan, dan hukum agama, dalam hal ini Islam. .(Ismail Saleh: 1989; 12-131) 
Perjalanan waktu dalam bingkai historis mendeskripsikan bahwa mendefinisikan hukum nasional tidaklah mudah. Banyak terjadi kontradiksi dan kontroversi dalam mewujudkan hukum nasional tersebut. Bersandar seluruhnya kepada hukum adat tidak dikehendaki. Demikian pula tidak seluruhnya kepada hukum Islam. Untuk yang terakhir ini ada bermacam-macam alasan dan proses yang menjauhkan Islam dari praktik formal. Formalisasi merupakan suatu usaha untuk membuat dan mengesahkan peraturan baru agar sah dan berlaku, antara lain dengan penyesuaian dan perubahan. Dalam bidang hukum, formalisasi sering dipakai dalam arti penyesuaian hukum dengan kebutuhan masyarakat. Proses atau upaya formalisasi hukum Islam( Amarullah Ahmad (1996: 53). dalam tata hukum nasional dimaksudkan sebagai usaha menerapkan hukum Islam yang normatif menjadi hukum Islam yang positif atau yang sering disebut usaha positifisme hukum Islam ke dalam tata hukum Indonesia.

Kenyataan hukum menggambarkan bahwa setelah Indonesia merdeka dan karena dorongan kesadaran hukum sewaktu dalam masa penjajahan dan dalam masa revolusi, diperjuangkan wujud hukum Islam (hukum agama) ada dalam hukum nasional.( Ahmad Taqwim, 2009:93). Hal ini merupakan perwujudan dari sikap kritis bahwa Indonesia tidak akan mengikuti begitu saja hukum penjajah atau hukum Eropa. Namun dalam aspek lain, formalisasi hukum agama menjadi tema yang tidak disepakati oleh mayoritas bangsa Indonesia. Formalisasi hukum Islam tentu berbeda dengan adopsi nilai-nilai yang bersumber dari agama Islam. Penduduk Indonesia adalah Penduduk terbesar manganut Agama Islam sehingga pentingnya menggunakan hukum Islam untuk menjadi hukum Nasional tersebut Islam adalah agama yang syumul. Mengatur seluruh aspek kehidupan manusia. Oleh karena itu Allah SWT mewajibkan kepada umatnya untuk senantiasa berhukum dengan hukum Allah dalam setiap perkara. Hal ini Allah wajibkan agar terciptanya keadilan. Dengan berbagai cara Allah memerintahkan kepada hamba-Nya agar berhukum dengan hukum Allah. Kadang dengan menggunakan kata perintah, ancaman bagi yang meninggalkan, atau dengan memuji bahwa Allah adalah sebaik-baik Zat pembuat hukum. Sebagaimana firman Allah : 


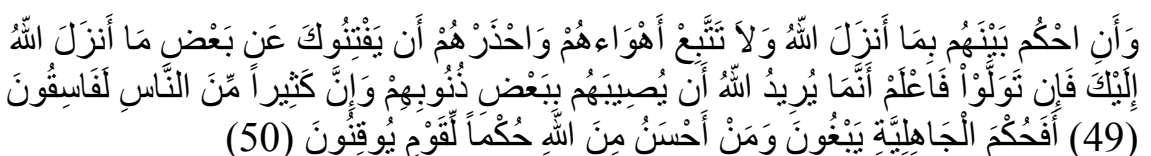

Artinya :"Dan hendaklah kamu berhukum dengan apa yang diturunkan Allah dan janganlah engkau mengikuti hawa nafsu mereka. Dan waspadalah terhadap mereka, jangan sampai mereka memperdayaimu atas sebagian yang Allah turunkan kepadamu. Jika mereka berpaling (dari hukum yang Allah turunkan) maka ketahuilah bahwa sesungguhnya Allah berkehendak menimpakan musibah kepada mereka karena dosa-dosa mereka. Dan sungguh kebanyakan manusia adalah orang-orang yang fasik (49) APakah hukum jahiliyah yang mereka kehendaki? Dan siapakah yang lebih baik dari Allah (dalam menetapkan hukum) bagi orang-orang yang yakin (50)”. (QS Al Maidah 49-50)

Di dalam ayat di atas Allah memerintahkan berhukum dengan hukum Allah dan mengancam orang-orang yang meninggalkan hukum Allah. Di akhir ayat Allah menutup dengan kalimat tanya yang menyatakan bahwa Dia-lah sebaik-baik pembuat hukum. Pada asalnya, berhukum kepada selain hukum Allah adalah terlarang, karena menyelisihi perintah Allah. Seringkali, berhukum dengan selain hukum Allah membuat pelakunya jatuh ke dalam kekafiran. Tentu saja, kaidah di atas akan berlaku apabila terpenuhi dhowabit (rambu-rambu) dan tidak adanya mawani' (penghalang untuk dijatuhkan vonis takfir tersebut).

Tulisan ini akan mendeskripsikan bagaimana hukum Islam diformalisasikan menjadi hukum nasional, dengan menggunakan dua pendekatan (approach), yaitu pendekatan historis proses formal tersebut terjadi sampai zaman kemerdekaan, dan pendekatan politik kebijaksaan pemerintah Republik Indonesia setelah kemerdekaan sampai sekarang.

\section{Arti Hukum Islam}

Ada beberapa istilah kunci yang tetap muncul ketika membicarakan hukum Islam, yakni syari'at, fiqh, qanun, fatwa, qadha, siyasah syar'iyah dan hukum.( Nur A. Fadhil Lubis, 1995: 2). Hukum Islam pada hakikatnya adalah hukum yang bersumber dan menjadi bagian dari agama] Islam.(Mohammad Daud Ali. 2000: 2) 
Mengingat pentingnya peristilahan ini, setiap orang dan kelompok cenderung memahaminya sesuai dengan kerangka pikirnya masingmasing.

Kata hukum Islam sebenarnya tidak ditemukan sama sekali dalam Alquran, namun yang ada dalam Alquran adalah kata syari'at, figh, hukm dan yang seakar dengannya. Dalam literatur Barat, hukum Islam merupakan terjemahan dari term "Islamic Law".) ( Fathurrahman Djamil. 1999: 55) Secara harfiah kata syari'ah dalam bahasa Arab berarti jalan yang lurus.( Muhammad Ali al-Sais. 1970:8-9) Menurut Abu Aal-Husayn Ahmad bin Faris bin Zakariyah, perkataan syariah berarti sesuatu yang terbentang jalan kepadanya. Abu Al-Husayn Ahmad bin Faris bin Zakariyah. 1979: 262)

Menurut ijma' ulama syari'at ialah hukum-hukum yang diadakan oleh Tuhan untuk hamba-hamba-Nya, yang dibawa oleh salah seorang Nabi-Nya yaitu Muhammad saw, baik hukum-hukum tersebut berhubungan dengan cara mengadakan perbuatan yaitu yang disebut sebagai "hukum-hukum cabang amalan", dan untuknya maka dihimpunlah ilmu fiqih atau berhubungan dengan cara mengadakan kepercayaan (i'tikad), yaitu yang disebut dengan hukum-hukum pokok" dan kepercayaan, dan untuknya maka dihimpunlah ilmu kalam. Syari'at (Syara') disebut juga agama (al-din dan millah).( Ahmad Hanafi. 1989: 89). Menurut Manna' al-Qaththan sebagaimana yang dikutip oleh Fathurrahman Djamil syari'at adalah segala ketentuan Allah swt yang disyari'atkan kepada hamba-Nya baik menyangkut akidah, akhlak maupun mu'amalah.( Fathurrahman Djamil,7)

Istilah syariah sebenarnya mempunyai arti yang luas, tidak hanya berarti fikih dan hukum, tetapi mencakup pula akidah dan akhlak.( Hamka Haq. 2009:41) Dengan demikian syariah mengandung arti bertauhid kepada Allah, menaati-Nya, beriman kepada rasul-rasulNya, kitab-kitab-Nya dan hari pembalasan. Singkatnya syariah mencakup segala sesuatu yang membawa seseorang menjadi berserah diri kepada Tuhan (Muslim). (Sa'ud ibn Sa'ad 'Ali Dhurayh. 1973:23) Menurut pendapat al-Amidi fiqh ialah ilmu tentang seperangkat hukum syara' yang bersifat furu'iyah (cabang) yang didapatkan melalui penalaran atau penelitian dan istidlal.( Shaif al-Din al-Amidi. 1958:8)

Fiqh adalah ilmu yang dihasilkan oleh pikiran serta ijtihad (penelitian) dan memerlukan kepada pemikiran dan perenungan. Oleh 
karena itu Tuhan tidak bisa disebut sebagai faqih (ahli dalam fiqih), karena bagi-Nya tidak ada sesuatu yang tidak jelas. Dengan demikian fiqih bukanlah syari'at, melainkan produk atau hasil dari syari'at itu sendiri yang digali para mujtahid (orang yang melakukan penelitian terhadap dalil baik itu Alquran maupun hadis). Ia hanya membicarakan amaliyah furu'iyah yang didasarkan pada dalil-dalil terperinci. Dalil yang digali itu sifatnya zhanny (dapat diinterpretasikan) bukan qath 'iy (yang tidak dapat diinterpretasikan).

Penerapan fikih ini dalam kehidupan sehari-hari bisa dalam bentuk fatwa ketika warga Muslim mempertanyakan ketentuan sesuatu hal kepada tokoh yang dianggap paling tahu fikih, yang dikenal dengan nama mufti. Fatwa lebih merupakan upaya sukarela masyarakat untuk menerapkan panduan Ilahi dalam mengatur tindaktanduk mereka, dan oleh karenanya ia lebih merefleksikan kondisi riil masyarakat. Mohammad Daud Ali mengatakan bahwa kalimat hukum yang dipakai dalam bahasa Indonesia saat ini berasal dari kata hukm ( (حكم) yang artinya norma atau kaidah ; ukuran, tolok ukur, patokan, pedoman yang dipergunakan untuk menilai tingkah laku atau perbuatan manusia dan benda. Kata ha-ka-ma dalam bahasa Arab dapat juga dimaknai dengan mencegah atau menolak. Mencegah ketidakadilan, kezaliman dan penganiayaan disebut hukum.( Hafizh Dasuki. 1997:157)

Kata hukum yang dikenal dalam bahasa Indonesia berasal dari bahasa Arab hukm yang berarti putusan (judgement) atau ketetapan (Provision). Dalam buku Ensiklopedi Hukum Islam, hukum berarti menetapkan sesuatu atas sesuatu atau meniadakannya. Bagi kalangan muslim, jelas yang dimaksudkan sebagai hukum adalah Hukum Islam, yaitu keseluruhan aturan hukum yang bersumber pada Alquran, dan untuk kurun zaman tertentu lebih dikonkritkan oleh Nabi Muhammad dalam tingkah laku Beliau, yang lazim disebut Sunnah Rasul. Ada dua kategori hukum yang lahir dari perintah Allah, yakni wajib dan sunnah, sedangkan firman dalam bentuk larangan melahirkan hukum haram dan makruh. Adapun firman Allah yang memberi keluasan bagi manusia dalam menentukan pilihan antara berbuat dan tidak, dikategorikan mubah (boleh), yang berindikasi boleh dilakukan dan boleh juga ditinggalkan, sehingga terkesan tak ada tuntutan di dalamnya.( Hamka Haq: 44)

\section{Pembahasan}


Penerimaan hukum Islam di Indonesia dapat berlaku jika diterima oleh hukum adat (teori receptie). Dasar hukum pemakaian teori ini adalah Wet op de Staatsinrichting van Nederland Indie (IS) tahun 1929 dalam Stb. 212, yang berusaha menghapuskan hukum Islam dari tata hukum Belanda. Menurut teori ini, hukum yang berlaku di masyarakat Indonesia bukanlah hukum Islam, melainkan hukum adat. Atau dengan kata lain teori receptie, yang membatasi bahwa hukum Islam baru dinyatakan dan disebut berlaku jika ia telah masuk/meresap dan diterima oleh dan sebagai hukum adat dalam masyarakat.

Teori resepsi sebagai suatu teori yang mempersempit ruang gerak berlakunya hukum Islam di Indonesia, yang oleh sebagian ahli hukum Indonesia menyebutnya sebagai teori iblis, dimunculkan, digagas oleh hasil pikir dari seorang Snouck Hurgronje. Kenyataan hukum menggambarkan bahwa setelah Indonesia merdeka dan karena dorongan kesadaran hukum sewaktu dalam masa penjajahan dan dalam masa revolusi, diperjuangkan wujud hukum Islam (hukum agama) ada dalam hukum nasional. Hal ini merupakan perwujudan dari sikap kritis bahwa Indonesia tidak akan mengikuti begitu saja hukum penjajah atau hukum Eropa. Namun dalam aspek lain, formalisasi hukum agama menjadi tema yang tidak disepakati oleh mayoritas bangsa Indonesia. Formalisasi hukum Islam tentu berbeda dengan adopsi nilai-nilai yang bersumber dari agama Islam.

\section{Teori Receptio in Complexu}

Teori receptio in Complexu menyatakan bahwa bagi orang Islam berlaku penuh hukum Islam sebab ia telah memeluk agama Islam walaupun dalam pelaksanaannya terdapat penyimpanganpenyimpangan. Teori ini berlaku di Indonesia ketika teori ini diperkenalkan oleh Prof. Mr. Lodewijk Willem Christian van den Berg. Teori Receptio in Complexu ini telah diberlakukan di zaman VOC sebagaimana terbukti dengan dibuatnya pelbagai kimpulan hukum untuk pedoman pejabat dalam menyeleaikan urusan-urusan hukum rakyat pribumi yang tinggal di dalam wilayah kekuasaan VOC yang kemudian dikenal senagai Nederlandsch Indie.

\section{Teori Receptie}

Teori Receptie menyatakan bahwa bagi rakyat pribumi pada dasarnya berlaku hukum adat. Hukum Islam berlaku bagi rakyat 
pribumi kalau norma hukum Islam itu telah diterima oleh masyarakat sebagai hukum adat. Teori Receptie dikemukakan oleh Prof. Christian Snouck Hurgronye dan kemudian dikembangkan oleh van Vollenhoven dan Ter Haar. Teori ini dijadikan alat oleh Snouck Hurgronye agar orang-orang pribumi jangan sampai kuat memegang ajaran Islam dan hukum Islam. Jika mereka berpegang terhadap ajaran dan hukum Islam, dikhawatirkan mereka akan sulit menerima dan dipengaruhi dengan mudah oleh budaya barat. Ia pun khawatir hembusan Pan Islamisme yang ditiupkan oleh Jamaluddin Al-Afgani berpengaruh di Indonesia.

Teori Receptie ini amat berpengaruh bagi perkembangan hukum Islam di Indonesia serta berkaitan erat dengan pemenggalan wilayah Indonesia ke dalam sembilan belas wilayah hukum adat. Teori Receptie berlaku hingga tiba di zaman kemerdekaan Indonesia.

\section{Teori Receptie Exit}

Teori Receptie Exit diperkenalkan oleh Prof. Dr. Hazairin, S.H. Menurutnya setelah Indonesia merdeka, tepatnya setelah Proklamasi Kemerdekaan Indonesia dan Undang-Undang Dasar 1945 dijadikan Undang-Undang Negara Republik Indonesia, semua peraturan perundang-undangan Hindia Belanda yang berdasarkan teori receptie bertentangan dengan jiwa UUD '45. Dengan demikian, teori receptie itu harus exit alias keluar dari tata hukum Indonesia merdeka.

Teori Receptie bertentangan dengan al-Qur'an dan Sunnah. Secara tegas UUD '45 menyatakan bahwa "Negara berdasar atas Ketuhanan Yang Maha Esa" dan "Negara menjamin kemerdekaan tiap-tiap penduduk untuk memeluk agamanya masing-masing dan untuk beribadat menurut agamanya dan kepercayaannya itu." Demikiandinyatakan dalam pasal 29 (1) dan (2).

\section{Teori Receptie A Contrario}

Teori Receptie Exit yang diperkenalkan oleh Hazairin dikembangkan oleh Sayuti Thalib, S.H. dengan memperkenalkan Teori Receptie A Contrario. Teori Receptie A Contrario yang secara harfiah berarti lawan dari Teori Receptie menyatakan bahwa hukum adat berlaku bagi orang Islam kalau hukum adat itu tidak 
bertentangan dengan agama Islam dan hukum Islam. Dengan demikian, dalam Teori Receptie A Contrario, hukum adat itu baru berlaku kalau tidak bertentangan dengan hukum Islam.

Kalau Teori Receptie mendahulukan berlakunya hukum adat daripada hukum Islam, maka Teori Receptie A Contrario sebaliknya. Dalam Teori Receptie, hukum Islam tidak dapat diberlakukan jika bertentangan dengan hukum adat. Teori Receptie A Contrario mendahulukan berlakunya hukum Islam daripada hukum adat, karena hukum adat baru dapat dilaksanakan jika tidak bertentangan dengan hukum Islam. Demikian uraian mengenai teori tentang berlakunya hukum Islam di Indonesia. Semoga bermanfaat. ( Hamka Haq. 2009 : 44)

\section{Metode Penelitian}

Jenis penelitiannya adalah Kepustakaan atau Penelitian Literatur. Ditinjau dari sudut pandang tempatnya, penelitian ini berbentuk studi perpustakaan (library research) yaitu "Penelitian yang datanya diambil dari sebagian atau seluruhnya dari perpustakaan. Contohnya artikel, laporan, buku-buku, majalah dan lainlainya”.(Prasetya Irawan, 1999: 487) Penelitian ini menggunakan pendekatan kualitatif "penelitian yang menggunakan latar alamiah, dengan maksud menafsirkan fenomena yang terjadi dan dilakukan dengan jalan melibatkan berbagai metode yang ada. latar alamiah bermaksud agar hasilnya dapat digunakan untuk menafsirkan fenomena yang dimanfaatkan untuk penelitian kualitatif dengan berbabagi macam metode penelitian yang biasanya dimanfaatkan adalah wawancara, pengamatan dan pemanfaatan dokumen." (Denzin dan Lincoln dalam Moleong, 2013:5) dalam hal ini peneliti menggunakan metode pemanfaatan dokumen untuk mengungkap dakwah nabi muhammad di madinah (analisis keberhasilan dakwah nabi dalam tinjauan sosiologi).

Teknik pengumpulan data dengan menghimpun dan menganalisis dokumen-dokumen, baik dokumen tertulis, gambar, hasil karya, maupun elektronik. Dokumen yang diperoleh kemudian dianalisis, dibandingkan dan dipadukan (sintesis) membentuk satu kajian yang sistematis, terpadu dan utuh. (Nilamsari 2014)

Cara menganalisis isi/ content analysis/kajian isi/dokumen ialah dengan memeriksa dokumen secara sistematik bentuk-bentuk 
komunikasi yang dituangkan secara tertulis dalam bentuk dokumen dengan obyektif. Teknik Kajian isi yaitu: 1). Menyesuaikan materi ke dalam model komunikasi. 2). Aturan analisis; materi yang dianalisis secara bertahap mengikuti aturan prosedur, yaitu membagi materi ke dalam satuan-satuan. 3). Kategori adalah pusat dari analisis. Aspekaspek interpretasi teks mengikuti pertanyaan penelitian, dimasukan ke dalam kategori. Kategori ini ditemukan dan direvisi di dalam proses analisis. Dalam makalah berjudul Qualitative Content Analysis karya Philipp Mayring (dalam Moleong 2007: 222). Jenis penelitian ini juga menggunakan penelitian yuridis normatif. Penelitian ini memfokuskan untuk mengkaji penalaran kaidah - kaidah atau norma - norma hukum positif. Pendekatan yuridis normatif dalam penelitian ini digunakan untuk menganalisis Aturan dan UndangUndang yang ada yang berkaitan dengan bahan hukum islam. (Johny Ibrahim, 2006: 295)

\section{Sejarah Proses Penerimaan Hukum Islam di Indonesia}

Sepanjang telaah tentang sejarah hukum di Indonesia, maka nampak dengan fakta yang ada, bahwa sejak berabad-abad lalu, hukum Islam itu telah menjadi hukum yang hidup (establish) di tengah-tengah masyarakat Islam di negeri ini. Hukum Islam masuk ke Indonesia seiring dengan masuknya Islam ke negeri ini pada abad ke13 Masehi atau pendapat lain mengatakan pada abad I Hijriah atau pada abad ketujuh/kedelapan Masehi.( Yusril Ihza Mahendra: 2009; 9)

Kehadiran Islam di Indonesia tidaklah menghadapi masyarakat yang steril atau vakum agama atau kepercayaan. Masyarakat Indonesia telah menganut berbagai bentuk kepercayaan lokal yang berwujud paham menekankan roh (animisme) dan adanya kekuatan di alam semesta (dinamisme).

Selain itu, dua agama besar dari India yaitu Hindu dan Budha telah terlebih dulu tertanam dalam masyarakat. Pendekatan kedua agama ini dan kepercayaan-kepercayaan lokal yang ada pada dasarnya sangat menekankan pengayaan spritual. Oleh karena itu kehadiran Islam pun harus menyesuaikan langgam penyiarannya dengan pengayaan spritual itu. Untuk itu, penyebaran agama Islam dilalui dengan proses olah rasa dengan menerapkan tiga alternatif pendekatan yaitu adaptasi, akomodasi, dan seleksi.( M. Ridwan Lubis. 1995;1)

Daerah yang pertama kali yang dimasuki oleh Islam adalah pesisir Utara pulau Sumatera dengan pembentukan masyarakat Islam 
pertama di Peureulak Aceh Timur dan kerajaan Islam pertama di Samudera Pasai, Aceh Utara.( Ramly Hutabarat. 2005:21) Sebagai gerbang masuk ke dalam kawasan nusantara, kawasan utara pulau Sumatera-lah yang kemudian dijadikan sebagai titik awal gerakan dakwah pendatang Muslim.

Berdasarkan riwayat sejarah yang ada, pada masa kerajaankerajaan Islam di Nusantara ini dimasa lampau, upaya untuk melaksanakan ajaran-ajaran Islam termasuk hukum-hukumnya, nampak mendapat dukungan yang besar, bukan saja dari para ulama, tetapi juga dukungan penguasa politik, yakni raja-raja dan para sultan. Masih dapat dilihat dan terlacak dengan baik jejak peninggalan kehidupan sosial keagamaan Islam dan pranata hukum Islam pada masa lalu di Kesultanan Aceh, Deli, Palembang, Goa dan Tallo di Sulawesi Selatan, Kesultanan Buton, Bima, Banjar, serta Ternate dan Tidore. Termasuk juga didalamnya di Yogyakarta, Surakarta dan Kesultanan Banten dan Cirebon di Jawa.

Dalam proses penyebaran agama Islam di kepulauan Nusantara, jasa para saudagar melalui metode bisnis dan perkawinan, tidak dapat diabaikan. Kedatangan mereka selain karena kepentingan bisnis juga untuk menyebarluaskan Islam di tempat yang mereka singgahi. Hal ini misalnya terlihat ketika seorang saudagar hendak menikah dengan seorang pribumi, maka wanita pribumi itu di Islamkan agamanya lebih dahulu dan pernikahannya kemudian dilangsungkan menurut ketentuan agama Islam. (Affan Su'aidi.: 2009:5-6) Dengan demikian proses Islamisasi penduduk pribumi di Nusantara lebih banyak karena faktor perkawinan yang muaranya adalah terjadi asimilasi budaya.

Angin perubahan mulai bertiup kala Belanda mulai menancapkan kekuatan dan kekuasaannya di Indonesia. Ismail Sunny membagi periodesasi sejarah hukum Islam pada masa Belanda kepada dua periode, yaitu periode penerimaan hukum Islam sepenuhnya ( teori receptie in complexu) dan periode penerimaan hukum Islam, jika diterima hukum adat (teori receptie).

Fase penerimaan hukum Islam sepenuhnya dimulai pada masa kesultanan-kesultanan Islam berlanjut sampai pada zaman datangnya Vereenigde Ost Compagnie (VOC) tahun 1602 dan berakhir pada tahun 1885. Sedangkan Bustanul Arifin dalam bukunya Pelembagaan Hukum Islam Di Indonesia memberi batasan periode ini sampai 1 April 1937. 
Kedatangan VOC tidaklah mengganggu kemapanan hukum Islam. Bahkan VOC mengakui keberadaan hukum Islam dan berusaha membukukan hukum Islam ke dalam berbagai kumpulan hukum untuk kepentingan penduduk bumiputera di wilayah yang mereka kuasai.( Bustanul Arifin. 1996: 35) Misalnya VOC menerapkan hukum kekeluargaan dalam bentuk peraturan Resolutie der Indische Regeering yang merupakan kumpulan aturan perkawinan dan kewarisan yang terkenal dengan nama Compendium Freijer. Inilah yang diberi dasar hukumnya dengan Regering Reglement (RR) tersebut. Antara lain dalam Pasal 75 RR dinyatakan: "oleh hakim Indonesia itu hendaklah diperlakukan Undang-undang Agama (goodsdiente wetter)...".( Ismail Sunny. 1996:131)

Pada masa-masa kedatangannya VOC hanyalah sebuah perusahaan dagang yang mempunyai hak istimewa dari pemerintah Belanda yang menganut kebijakan non-interferenci (tidak campur tangan) dalam masalah agama dan kekeluargaan penduduk pribumi.( Nur A. Fadhil Lubis. 1995:78-80) Keadaan yang demikian dapat dilihat dari kebijakan Hindia Belanda dalam Statuta Batavia (1862) yang menyatakan bahwa hukum dan pranata yang ada supaya dibiarkan berlaku terus, termasuk didalamnya hukum dan kelembagaan Islam. Kemudian disusun secara lebih sistematis sesuai dengan tradisi Belanda yang disebut dengan Compendium Freijer yang memuat aturan-aturan hukum perkawinan dan kewarisan sesuai dengan hukum Islam versi mazhab Syafi'i.

Kebebasan yang diberikan kepada umat Islam untuk melaksanakan hukum Islam berakhir ketika Kerajaan Belanda mengambilalih kekuasaan dari VOC sekitar abad ke-18. ( Saidus Syahar. 1996:133)

Fase kedua penerimaan hukum Islam jika diterima oleh hukum adat (teori receptie).( Saidus Syahar. 1996:133) Dasar hukum pemakaian teori ini adalah Wet op de Staatsinrichting van Nederland Indie (IS) tahun 1929 dalam Stb. 212, yang berusaha menghapuskan hukum Islam dari tata hukum Belanda. Menurut teori ini, hukum yang berlaku di masyarakat Indonesia bukanlah hukum Islam, melainkan hukum adat. Atau dengan kata lain teori receptie, yang membatasi bahwa hukum Islam baru dinyatakan dan disebut berlaku jika ia telah masuk/meresap dan diterima oleh dan sebagai hukum adat dalam masyarakat.( Sajuti Thalib. 1985: 13) 
Teori resepsi sebagai suatu teori yang mempersempit ruang gerak berlakunya hukum Islam di Indonesia, yang oleh sebagian ahli hukum Indonesia menyebutnya sebagai teori iblis, ( Daud Ali, Op.Cit., hlm. 22) dimunculkan, digagas oleh hasil pikir dari seorang Snouck Hurgronje.

Padahal sebelum Snouck Hurgronje berpetualang di Indonesia tahun 1889, dan menjadi penasihat urusan pribumi dan Islam pemerintah Hindia Belanda, para ilmuan, politikus, dan penguasa pemerintah Belanda menganut satu paham dan keyakinan melalui penelitian yang mereka lakukan tentunya, bahwa sisi hukum yang mengatur tertib masyarakat adalah hukum agama. Maka bagi orang Islam Indonesia berlaku hukum Islam oleh karena mereka telah memeluk agama Islam yang oleh Lodewijk William Christian van den Berg kemudian memberi nama dengan sebutan untuknya dengan teori receptie in complexu.

Namun setelah Snouck Hurgronje berada di Indonesia dengan tugas penelitian terhadap suku Aceh dan Islam di Jawa, ia kemudian mengkritik teori van den Berg tersebut dan mengemukakan pendapat dan buah pikirannya yang berbeda yaitu yang ia sebut dengan theorie receptie artinya bahwa hukum yang mengatur tertib masyarakat di Indonesia adalah hukum adat asli, sedang hukum agama (Islam) hanya berlaku pada sebahagian kecil yang telah diterima, meresap dan sesuai dengan hukum adat. Atau dengan istilah yang oleh Mohammad Daud Ali bahwa teori resepsi adalah teori yang menyatakan hukum Islam bukan hukum kalau belum diterima ke dalam dan oleh hukum adat.( Mohammad Daud Ali :141)

Oleh karena itulah dalam Pasal 124 ayat (2) IS tahun 1929 disebutkan: "Dalam hal terjadi perkara perdata antara sesama orang Islam akan diselesaikan oleh hakim agama Islam apabila hukum adat mereka menghendakinya dan sejauh itu tidak ditentukan lain dalam satu ordonansi".

Setelah Thomas Stanford Raffles menjabat sebagai gubernur selama 5 tahun (1811-1816), pihak Belanda berusaha keras mencengkeram kuku-kuku kekuasaannya di wilayah ini. Namun hal itu menemui kesulitan akibat adanya perbedaan agama antara penjajah dengan rakyat jajahannya, khususnya umat Islam yang mengenal konsep dar al-Islam dan dar al-harb.(Muhammad Ihsan, www.abulmiqdad.multiply.com/journal/item/13., diakses tanggal 10 Juni 2010) 
Itulah sebabnya pemerintah Belanda selalu mengupayakan segala cara untuk menyelesaikan masalah tersebut. Cara-cara yang dilakukan pemerintah Belanda antara lain dengan:

1. Menyebarkan agama Kristen kepada rakyat pribumi;

2. Membatasi keberlakuan hukum Islam hanya kepada aspek-aspek batiniah (spritual) saja.

Lemahnya posisi hukum Islam ini terus terjadi hingga menjelang berakhirnya kekuasaan Hindia Belanda di wilayah Indonesia pada tahun 1942.

\section{Kebijakan Politik Hukum Indonesia Bagi Hukum Islam dalam Tata Hukum Indonesia}

Dalam kajian ilmu hukum, ada yang disebut hukum positif (ius constituendum) dan hukum yang dicita-citakan (ius constitutum).( A. Rahmat Rosyadi, M. Rais Ahmad. 2006:95) Hukum positif adalah hukum yang berlaku saat ini di suatu negara. Hukum yang dicita-citakan yaitu hukum yang hidup di masyarakat, tetapi belum menjadi hukum positif secara legal formal. Hukum Islam sebagai tatanan hukum yang dipedomani dan ditaati oleh mayoritas penduduk dan masyarakat Indonesia adalah hukum yang telah hidup dalam masyarakat, dan merupakan sebagian dari ajaran dan keyakinan Islam yang eksis dalam kehidupan nasional, serta merupakan bahan dalam pembinaan dan pengembangannya. Fakta sejarah perjalanan hukum di Indonesia mendeskripsikan, bahwa kehadiran hukum Islam dalam hukum nasional merupakan perjuangan eksistensi. Teori eksistensi merumuskan keadaan hukum nasional Indonesia masa lalu, masa kini, dan masa datang, menegaskan bahwa hukum Islam itu ada dalam hukum nasional Indonesia, baik tertulis maupun yang tidak tertulis.( Mardani. 2009:5)

Dalam konteks Indonesia, eksistensi hukum Islam dalam tataran aplikatif menjadi hukum positif (ius constituendum) hanya yang berkaitan dengan hukum privat yaitu ubudiah dan muamalah. Sedangkan yang berkaitan dengan hukum publik Islam sampai hari ini masih menjadi hukum yang dicita-citakan. Ironis jika dilihat dari aspek manapun, bahwa sesuatu yang bersifat publik keberlakuannya malah tidak dilegislasi tetapi yang berkaitan dengan masalah privat justeru dijadikan hukum positif. Walaupun begitu, seluruh upaya untuk lebih menerapkan hukum Islam di Indonesia patut diapresiasi dengan baik, ditengah berbagai halangan dan tantangan yang datang 
dari segala penjuru menolak eksistensi hukum Islam ke arah kodifikasi, unifikasi, kompilasi, unifikasi hukum Islam ke dalam hukum positif. Pada dasarnya implementasi hukum Islam di Indonesia dapat dilaksanakan melalui dua jalur. Pertama dengan jalur iman dan takwa. Artinya pemeluk agama Islam melaksanakan hukum Islam secara pribadi sesuai dengan kualitas keimanan dan ketakwaannya. Pelaksanaan hukum Islam melalui jalur ini dijamin oleh negara sesuai dengan Pasal 29 ayat (2) UUD 1945.

Jalur kedua melalui perundang-undangan dalam berbagai undang-undang dan peraturan lainnya. Jaih Mubarok mengemukakan sebagaimana yang dikutip oleh Ali Imron HS bahwa salah satu bentuk pemikiran hukum Islam adalah qanun atau peraturan perundang-undangan.( Ali Imron HS. 2009: 68) Penetrasi hukum Islam ke dalam peraturan perundangan di Indonesia dapat dibedakan menjadi dua model, yaitu pertama, penetrasi hukum Islam ke dalam peraturan perundangan secara substantif dan tidak dinyatakan secara eksplisit sebagai hukum Islam. Model pertama ini jelas-jelas tidak menggunakan label Islam sama sekali. Sebagaimana halnya hukum nasional secara umum yaitu bersifat netral, dengan definisi yang sangat vulgar tidak menunjukkan khas agama dan identitas kelompok tertentu. Dengan kondisi seperti ini, maka bagi orang-orang yang sering terlena dengan embel-embel atau berbagai macam lebel yang antiagama, serta orang yang sulit mengetahui esensi sesuatu, maka akan ada sangkaan bahwa hukum itu adalah hukum nasional bukan hukum Islam. Hal ini terjadi karena keberadaan hukum Islam itu hanya dalam bentuk ide, bukan dalam bentuk istilah-istilah dalam format penyajian umum yang dikenal dalam kitab-kitab kuning. Inilah yang kemudian dikenal dengan Islam substantif. Artinya Islam yang lebih mengedepankan hal-hal yang bersifat subtansial, dan tidak terjebak dalam hal-hal yang simbolis.( Zulfikar. 2009: 185)

Keberadaan hukum Islam seperti ini tidak ditampilkan dalam spanduk-spanduk dan propaganda belaka meskipun esensinya ada. Hukum Islam dalam bentuk ini telah mengalami modifikasi dalam bentuk netral, karena telah terserap dalam hukum nasional secara umum. Hal yang terpenting adalah esensi ajaran Islam tetap diamalkan sebagaimana mestinya. Banyak contoh peraturan perundangan secara substantif dan tidak dinyatakan secara eksplisit sebagai hukum Islam, misalnya UU No. Tahun 1974 tentang Perkawinan, yang banyak mengambil hukum Islam secara substantif. 
Ada lagi UU No. 7 Tahun 1992 tentang Perbankan jo. PP No. 70 dan No.72/1992 tentang Bank Berdasarkan Prinsip Bagi Hasil.

Model kedua, penetrasi hukum Islam ke dalam peraturan perundangan yang secara eksplisit dinyatakan sebagai hukum Islam. Melalui jalur ini banyak sekali hukum Islam yang telah diakomodir oleh negara. Antara lain UU No. 7 Tahun 1989 tentang Peradilan Agama, UU No. 3 Tahun 2006 tentang Perubahan atasa UU No.7 Tahun 1989 tentang Peradilan Agama, UU No.17 Tahun 1999 tentang Penyelenggaraan Ibadah Haji, UU No. 38 tentang Pengelolaan Zakat, UU No. 21 Tahun 2008 tentang Perbankan Syariah, UU No. 41 Tahun 2004 tentang Wakaf. Fenomena tersebut tidak terlepas dari adanya kecenderungan masyarakat Indonesia saat ini menunjukkan bahwa mayoritas muslim ingin semakin menegaskan jati diri sejelas mungkin dalam arti kekuasaan politik serta aspirasi pembentukan dan penerapan hukum yang didasarkan dan bersumber pada norma-norma dan nilai-nilai hukum Islam.( www.legalitas.org., diakses tanggal 21 September 2008)

Implementasi hukum Islam di Indonesia secara universal sebenarnya telah terakomodir dan terlaksana dengan baik, meskipun masih terbatas dalam masalah hukum privat. Munculnya beberapa peraturan perundang-undangan seperti di atas, mendeskripsikan bahwa hukum Islam eksis di negeri ini. Meskipun dalam praktiknya selama ini terjadi kompromi atau tarik ulur antara hukum Islam yang dianggap mewakili umat Islam beserta tokohnya dan hukum sekuler yang dianggap mewakili pemerintah.

Proses tarik ulur atau kompromi seperti ini, dalam sejarah Islam dikenal dengan konsep qanun, yaitu legislasi hukum Islam oleh negara atau pemerintah namun lebih terdominasi oleh pertimbangan siyasah shar'iyyah (politik hukum atau penentuan hukum dengan pertimbangan faktor politik). Konsep dasar siyasah shar'iyyah dibuat untuk melakukan kebijakan yang menghendaki kemaslahatan melalui aturan yang tidak bertentangan dengan agama. Walaupun demikian yang terjadi, tapi terlihat dengan jelas dan kasat mata bahwa syariat Islam, hukum Islam maupun fikih Islam adalah hukum yang hidup dalam masyarakat Indonesia. Mengingat Indonesia adalah negara yang berpenduduk majemuk dengan segala potensi konflik di dalamnya, maka dalam hal hukum keluarga dan kewarisan, maka hukum Islam itu tetaplah dinyatakan sebagai hukum yang berlaku. 
Terhadap hal-hal yang berkaitan dengan hukum perdata lainnya, seperti perbankan dan asuransi, negara dapat pula mentransformasikan kaidah-kaidah hukum Islam di bidang itu dan menjadikannya sebagai bagian dari hukum nasional. Fakta historis terbentuknya hukum nasional Indonesia juga memberikan deskripsi bahwa hukum Islam merupakan salah satu elemen penting pendukung disamping hukum adat dan hukum Barat. Hukum Islam telah turut serta memberikan kontribusi norma-norma dan nilai-nilai hukum yang berlaku di dalam kehidupan masyarakat Indonesia. Pembentukan hukum nasional merupakan suatu proses perubahan bentuk dari hukum tidak tertulis menjadi hukum yang tertulis. Namun demikian hukum tidak tertulis juga merupakan bagian dari hukum nasional. Oleh karena itulah bentuk hukum tertulis tertentu diunifikasikan, utamanya dalam bentuk hukum yang relatif netral, sedangkan hukum yang sifatnya sensitif (erat kaitannya dengan keyakinan/akidah masyarakat) usaha untuk mempositifkannya masih mengandung permasalahan besar.

Berkaitan dengan hal itu, maka pengembangan hukum Islam di bidang hukum keluarga merupakan upaya unifikasi secara khusus bagi orang Islam, seperti yang ada dalam Kompilasi Hukum Islam (KHI), yang merupakan buah unifikasi dari keanekaragaman hukum Islam dari pemikiran fuqaha di pelbagai kitab fiqh. Formalisasi hukum Islam ke dalam hukum nasional terjadi dalam berbagai peraturan perundang-undangan, terutama hukum perdata. Kemudian proses transformasi hukum Islam dilakukan dengan memasukkan asas-asas hukum Islam ke dalam hukum nasional. Formalisasi asasasas tersebut tanpa menggunakan label hukum Islam, tetapi diserap dalam hukum nasional. Formalisasi hukum Islam dalam pembentukan hukum nasional juga dilakukan dalam bentuk produk pengadilan, baik melalui pengadilan agama maupun pengadilan umum. (Cik Hasan Bisri. 1998:185)

Formalisasi hukum Islam sebagai salah satu tatanan hukum ke dalam hukum nasional, secara umum, terakomodasi dalam sasaran pembangunan nasional di bidang hukum khususnya tentang materi hukum nasional. Namun penerapan dan penegakan hukum dalam masyarakat tergantung kepada empat unsur, yaitu: Pertama, perangkat hukum yang menjamin kepastian, perlindungan, dan keterttiban hukum yang intinya keadilan dan kebenaran. Kedua, aparatur penegak hukum yang tanggung menerapkan hukum dan 
menyelami rasa hukum dan keadilan. Ketiga, kesadaran hukum masyarakat yang intinya menghargai dan mematuhi hukum yang berlaku. Keempat, sarana dan prasarana yang dibutuhkan baik berupa kelembagaan maupun fisik.( (Cik Hasan Bisri. 1998:185)

\section{Simpulan}

formalisasi hukum Islam jika dilakukan secara substantif, tidak akan dapat dilepaskan dan harus didahului oleh referensi hsitoris dengan pertimbangan konstitusional dan sejarah bangsa. Proses tersebut tidak terlepas dari perjalanan sejarah hukum Islam di Indonesia, dan kebijaksanaan politik hukum Indonesia dalam menempatkan kedudukan hukum Islam dalam tata hukum nasional.

Hal ini dapat dilihat dari munculnya beberapa undang-undang yang bernuansa Islam, seperti UU No.1 Tahun 1974 tentang Perkawinan, Kompilasi Hukum Islam, KHI, UU No.7 Tahun 1989 tentang Peradilan Agama, UU No.3 Tahun 2006 tentang Perubahan atas UU No.7 Tahun 1989 tentang Peradilan Agama, UU No.17 Tahun 1999 tentang Penyelenggaraan Ibadah Haji, UU No. 38 tentang Pengelolaan Zakat, UU No. 21 Tahun 2008 tentang Perbankan Syariah, UU No. 41 Tahun 2004 tentang Wakaf. 


\section{DAFTAR PUSTAKA}

Al-Din al-Amidi, Shaif. 1958. Al-Ihkam fi Ushul al-Ahkam. Muassasah al-Halabi :Kairo.

Al-Husayn Ahmad bin Faris bin Zakariyah, Abu. 1979. Mu'jam Maqayis al-Lughah, Juz III. Ttp: Dar al-Fikr li al-Taba'ah wa al-Nasyr wa al-Tawzi.

Ali al-Sais, Muhammad. 1970. Nasy'at al-Fiqh al-Ijtihadiy wa Athwaruh, Kairo: Majma' al-Buhuts al-Islamiyah.

Ali Imron HS. 2009. Pertanggungjawaban Hukum Konsep Hukum Islam dan Relevansinya Dengan Cita Hukum Nasional Indonesia, Semarang: Walisongo Press.

Ali, Mohammad Daud. 2000. Hukum Islam Pengantar Ilmu Hukum dan Tata Hukum Islam di Indonesia. PT. Raja Grafindo Persada: Jakarta.

Ali, Mohammad Daud. Hukum Islam Dan Masalahnya di Indonesia, dalam Mimbar Hukum No.31 Tahun VIII 1997, Yayasan alHikmah, Jakarta.

Arfa. Faisar Ananda, "Syariat Islam Yang Mana?" Pertanyaan Bagi Penerapan Syariat Islam Di Indonesia dalam Muhammad Iqbal, Azhari Akmal Tarigan (Editor). 2004. Syariat Islam di Indonesia Aktualisasi Ajaran dalam Dimensi Ekonomi, Politik, dan Hukum. CV Misaka Galiza: Jakarta.

Arifin, Bustanul. 1996. Pelembagaan Hukum Islam Di Indonesia. Gema Insani Press: Jakarta.

Aulawi, Wasit. 1996. Sejarah Perkembangan Hukum Islam, dalam Amarullah Ahmad (ed.). Dimensi Hukum Islam Dalam Sistem Hukum Nasional, Gema Insani Press: Jakarta.

Azizy, Qodri. 2004. Hukum Nasional Eklektisisime Hukum Islam \& Hukum Umum, Edisis Revisi Teraju: Jakarta. 
Bisri, Cik Hasan. 1998. Peradilan Agama Di Indonesia. PT Raja Grafindo Persada :Jakarta.

Dasuki, Hafizh. 1997. Ensiklopedi Hukum Islam. Ichtiar Baru van Hoeve :Jakarta.

Effendy, Bahtiar. 1998. Islam dan Negara: Transformasi Pemikiran dan Praktik Politik Islam di Indonesia. Jakarta: Paramadina.

Hanafi, Ahmad. 1989. Pengantar dan Sejarah Hukum Islam. Bulan Bintang: Jakarta.

Haq, Hamka. 2009. Islam Rahmah Untuk Bangsa RMBOOKS: Jakarat.

Ibn Sa'ad 'Ali Dhurayh, Sa'ud. 1973. Al-Tanzhim al-Qadha'i fi alMamlakah al-'Arabiyah. Matabi' Hanifah li al-Ubset: Riyadh.

Joseph, Schacht. 1985. Pengantar Hukum Islam. Dirjen Binbaga Islam Departemen Agama RI: Jakarta.

Juhaya S. Praja. 1994. Hukum Islam Di Indonesia. PT. Remaja Rosdakarya :Bandung.

Ka'bah, Rifyal. 2007. Kodifikasi Hukum Islam Melalui UndangUndang Negara Di Indonesia, Makalah disampaikan pada Seminar Nasional Kompilasi Hukum Ekonomi Syariah. Kerja Sama Fakultas Syari'ah IAIN Sumatera Utara Dengan Mahkamah Agung RI tanggal 27 Oktober 2007.

Lubis, Nur A. Fadhil. Transformasi Hukum Islam Di Indonesia Suatu Refleksi. Makalah disampaikan dalam Seminar Refleksi 50 Tahun Indonesia Merdeka yang Diselenggarakan Senat Mahasiswa Fakultas Syari'ah IAIN Sumatera Utara Medan tanggal 14 Oktober 1995.

Lubis, M. Ridwan. 1995. Setengah Abad Proses Transformasi Pemikiran Islam Di Indonesia, Makalah disampaikan pada Seminar Refleksi 50 Tahun Indonesia Merdeka yang 
diselenggarakan Senat Mahasiswa Fakultas Syari'ah IAIN Sumatera Utara pada tanggal 14 Oktober 1995.

Lubis, Nur A. Fadhil. 1995. Hukum Islam. Pustaka Widyasaran: Medan.

Mardani. 2009. Hukum Acara Perdata Peradilan Agama \& Mahkamah Syar'iyah. Sinar Grafika: Jakarta.

Muslehuddin, Muhammad. Tth. Philosophy of Islamic Law and The Orientalist. Islamic Publucation L.T.D, Shah Alam Market: Lahore.

Ramly Hutabarat. 2005. Kedudukan Hukum Islam dalam Konstitusikonstitusi Indonesia dan Peranannya dalam Pembinaan Hukum Nasional. Pusat Studi Hukum Tata Negara Universitas Indonesia: Jakarta.

Rosyadi, Rahmat M. Rais Ahmad. 2006. Formalisasi Syariat Islam dalam Perspektif Tata Hukum Indonesia, Penerbit Ghalia Indonesia :Bogor.

Saleh, Ismail. "Wawasan Pembangunan Hukum Nasional". Kompas, edisi 1 dan 2 Juni 1989.

Su'aidi, Affan. Hukum Islam Pada Masa Penjajahan Belanda Kajian Historis Terhadap Pemberlakuan Hukum Islam di Indonesia dalam Fuji Rahmadi P (editor). 2009. Pembaharuan Hukum Islam Di Indonesia Menggugat Kemapaman Tradisi. Citapustaka Media Perintis :Bandung.

Sunny, Ismail. Kedudukan Hukum Islam dalam Sistem Ketatanegaraan Indonesia dalam Amrullah Ahmad (editor). 1996. Dimensi Hukum Islam Dalam Sistem Hukum Nasional. Gema Insani Press : Jakarta.

Syahar, Saidus. 1996. Asas-Asas Hukum Islam.Alumni: Bandung. 
Taqwim, Ahmad. 2009. Hukum Islam Dalam Perspektif Pemikiran Rasional, Tradisional, dan Fundamental. Walisongo Press: Semarang.

Thalib, Sajuti. 1985. Receptio A Contrario. Bina Aksara: Jakarta. Zuffran Sabrie (ed.). 1990. Peradilan Agama dalam Wadah Negara Pancasila. Antara: Jakarta.

Zulfikar. Pembaharuan Hukum Islam Di Indonesia dalam Fuji Rahmadi (Editor). 2009. Pembaharuan Hukum Islam Di Indonesia Menggugat Kemapaman Tradisionalisme. Citapustaka Media Perintis: Bandung.

Ikhsan, Muhammad. "Hukum Islam Di Indonesia: Dulu Dan Sekarang", $\quad$ www.abulmiqdad.multiply.com/journal/item/13., diakses tanggal 10 Juni 2010.

Febriansyah, Reza Fikri. "Eksistensi Hukum Islam Dalam Struktur Hukum Nasional Indonesia". www.legalitas.org., diakses tanggal 21 September 2008.

Mahendra, Yusril Ihza. "Hukum Islam dan Pengaruhnya Terhadap Hukum Nasional Indonesia." www.yusril.ihzamahendra.com. Diakses tanggal 29 Maret 2009. 